\title{
Formulation and Development of Milk Based Breakfast Drink
}

\author{
By \\ CHINTHAKA PRASANNA SAMARASEKARA
}

Thesis submitted to the University of Sri

Jayewardenepura, Sri Lanka for the award of the degree of

Masters of Science in Food Science and Technology

2008 


\section{Formulation and Development of Milk Based}

\section{Breakfast Drink}

By

C.P. SAMARASEKARA

M.Sc.

2008 


\section{DECLARATION}

The work described in this thesis was carried out by me under the supervision of Dr. K.K.D.S. Ranaweera, Head, Department of Food Science and Technology, University of Sri Jayewardenepura and Ms. I. Amarasekara, Quality Assurance Manager, Kotmale Milk Company Pvt. Ltd, Mulleriyawa .Sri Lanka. A report on this had not been presented or accepted in any previous application for a degree.

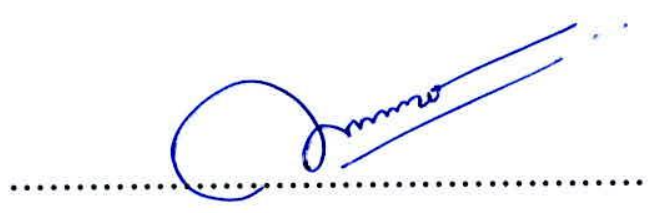

C.P. Samarasekara 
We hereby certify that the above statement made by the candidate is true and that this thesis is suitable for submission to the University for the purpose of evaluation.

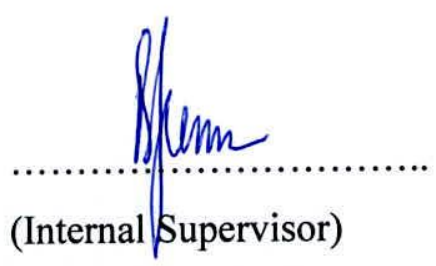

Dr. K.K.D.S. Ranaweera

Head,

Department of Food Science and Technology,

Faculty of Applied Sciences,

University of Sri Jayewardenepura,

Sri Lanka.

Date:

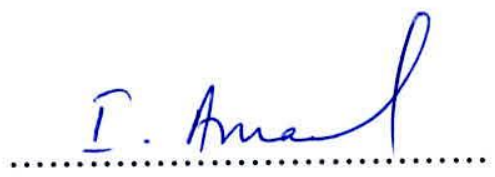

(External Supervisor)

Ms. I. Amarasekara,

Quality Assurance Manager,

Kotmale Milk Company Pvt, Ltd, Siri Sumana Mawata, Mulleriyawa,

Sri Lanka.

Date:.......6.............99 
Affectionately dedicated

to

My Parent and Teachers 


\section{Table of contents}

Table of content

List of Table

vi

List of figures

vii

Acknowledgement

viii

Abstract

ix

1.0 Introduction

1.1 Introduction

1

1.2 Objectives 2

2.0 Review of Literature 3

2.1 Food requirements 3

2.2. Available Energy of Nutrient 4

2.2.1. Carbohydrates 4

2.2.2. Lipid 5

2.2.2.1 Role of Fat and Oil in Biological System 6

2.2.3. Protein 6

2.2.3.1. Role of Protein in biological System 7

2.2.4. Enzyme 8

2.2.5. Vitamin 8

2.2.6. Mineral 9

2.2.7. Food Color 10

$\begin{array}{ll}\text { 2.2.8. Food Flavor } & 10\end{array}$

2.2.9. Food Additives 11

2.3. Breakfast Drink 11

2.4. Indigents of Breakfast Drink 11

2.4.1. Cow Milk 11

2.4.1.1. Secretion of Milk 12

2.4.1.2. The Chemistry of Milk 12

$\begin{array}{ll}\text { 2.4.1.3. Composition of Cow's Milk } & 12\end{array}$ 
2.4.1.4. Milk Fat

2.4.1.5. Protein in Milk

2.4.1.6. Class of Milk Protein

2.4.1.7. Casein

2.4.1.8 Whey Protein

2.4.1.9. Enzyme in Milk

2.4.1.10. Lactose

2.4.1.11. Vitamin in Milk

2.4.1.12. Mineral and Salts in Milk

2.4.1.13. Physical Properties of Milk

2.4.1.14. Bacteria in Milk

2.4.2. Soybean Composition

2.4.2.1. Nutritional composition Soybean 18

2.4.3. Cereal

2.4.4. Rice

2.4.4.1. Composition of Rice

2.4.4.2. Nutritional Factors of Rice

2.4.4.3. Rice Germination

2.4.4.4. Processing of Rice

2.5. Process Requirement

2.6. Resazurin Test 26

2.7. LTLT Pasteurization 26

2.8. HTST Pasteurization 26

2.9. UHT Treatment 27

2.10. Cooling 27

2.11. Microbial Culture 28

2.11.1.Differant Culture Media 28

2.11.2. Type of Different Culture media 28

2.11.3. Nutrient Agar (NA) 29

2.11.4. Pour Plate Techniques 29

$\begin{array}{ll}\text { 2.11.5. Agar } & 30\end{array}$ 
3.0 Materials and Methodology 31

3.1 Materials 31

3.1.1 Preparation of Molted Rice flour 31

3.1.2. Preparation of Soya Flour 31

3.1.3 Preparation of Breakfast Drink 31

3.1.4 Proximate analysis $\quad 33$

3.1.4.1 Determination of Moisture content -Oven drying method 32

3.1.4.2Determination of Free fat - Soxhlet Extraction method 32

3.1.4.3 Determination of Total Fat $\quad 32$

3.1.4.4 Determination of Protein 33

3.1.4.5 Determination of Crude Fibre 33

3.1.4.6 Determination of Ash $\quad 34$

$\begin{array}{ll}\text { 3.2 Methodology } & 35\end{array}$

3.2.1 Preparation of the Molted Rice flour 35

3.2.2 Preparation of Soya flour $\quad 36$

3.2.3 Preparation of Breakfast drink 36

3.2.4Assessment of sensory qualities $\quad 37$

$\begin{array}{ll}3.2 .5 \text { Testing criteria } & 37\end{array}$

3.2.6 Preparation of variety and testing the samples $\quad 37$

$\begin{array}{ll}3.2 .7 \text { Statistical Analysis } & 37\end{array}$

3.2.9 Proximate analysis $\quad 38$

3.2.9.1 Determination of Moisture content 38

3.2.9.2 Determination of Lipids 38

3.2.9.2.1 Determination of free fat -Soxhlet Extraction method 38 
3.2.9.2.2 Determination of Total fat

3.2.9.3 Determination of Proteins

3.2.9.4 Determination of Crude fibre

3.2.9.5 Determination of Ash

3.2.9.6 Determination of Carbohydrates

4.0 Results and Discussion

4.1 Preparation of milk based cereal breakfast drink

4.2 Sensory Analysis

4.3 Selection of best breakfast drink sample

4.3.1. Taste

4.3.2. Color

44

4.3.3. Texture/mouth feel

44

4.3.4. Appearance

45

4.3.5. Smell 45

4.3.6. Overall acceptability 45

4.4 Proximate analysis of selected best product 46

4.5 Shelf life evaluation 46

4.6 Microbiology Assessment 46

4.6.1 Microbiology Quality of the final product 47

5.0 Conclusion and Recommendation 48

5.1 Conclusion 48

5.2. Recommendation 48

REFERENCES

Appendix 01 50

Appendix 02 51

Appendix 03 52

Appendix 04 54

Appendix 05 
Appendix 06

Appendix 07

Appendix 08

Appendix 09

Appendix 10

Appendix 11

62

Appendix 12

63

Appendix 13

64 


\section{List of Table}

2.1. Nutrient Available Energy

2.2. Recommendation Daily Allowances of Vitamin and diseases to their acute deficiency

2.3. Biological Function of some Minerals

2.4. Main Constituent of cow's Milk

2.5. Nutritional Composition of Soybean

2.6. Nutritional Composition of Rice

4.1 summarizes the estimated mediums and sum of rank for each attribute tested 


\section{List of Figure}

3.1. Ingredients of Breakfast Drink 33

4.1. Coliform Plates of Finished Product. $\quad 50$

4.2. TPC Plate of Finished product $\quad 50$

4.3. TPC Plate of Finished product during shelf life $\quad 50$

4.4. TPC Plate of Finished product after shelf life $\quad 50$ 


\section{Acknowledgment}

I wish to express my first and foremost appreciation to my internal supervisor, Dr. K.K.D.S. Ranaweera, Head, Department of Food Science and Technology, Faculty of Applied Sciences, University of Sri Jayewardenepura for the kind assistance and guidance given throughout the period of this research project.

I extend my sincere gratitude to my external supervisor, Ms. I. Amarasekara, Quality Assurance Manager, Kotmale Milk Company Pvt. Ltd. for the expert guidance and invaluable assistance given to me to make research possibilities.

Also, I would like to thank everyone in the Food Science laboratory in the University of Sri Jayewardenepura, who helped me in various ways to conduct my research. 


\begin{abstract}
Breakfast is the most important meal of the day. A good breakfast provides necessary nutrients and good fuel to get the body functions. Breakfast drink is made up of milk, rice and soybean which provide an excellent source of carbohydrate, protein, fat, fibre, vitamin and minerals .Breakfast drink as a wholesome food product is suitable for children, adults and pregnant mothers. The breakfast cereal drink will be the most popular and usable strategy to enhance and increase human health condition up to higher level. The objective of the study was to formulate nutritious and economical cereal breakfast drink using fresh milk as a base.

Breakfast drink samples were formulated and made by adding various ratios of milk, soybean and rice of the total weight. Breakfast drinks samples were evaluated organoleptically by a group of panelists using a statistical analysis in order to find the best formula. The selected best formula was adjusted by adding stabilizer flavor enhancers and color. The best formula was finalized by sensory evaluation and statistical analysis. The selected samples were stored at $+4^{\circ} \mathrm{C}$ to determine development of any defects in specific physical, chemical, biological and sensorial properties during the expected shelf life period. Proximate analyses were used to determine the nutritional composition of the sample selected. The sensory quality, acidity and $\mathrm{pH}$ of the breakfast drink were monitored at weekly intervals during shelf life.

Better consumer acceptable wholesome breakfast drink can be prepared with moisture is $73.30 \%$, free fat is $0.75 \%$, total fat is $7.42 \%$, protein is 4.20 , crude fibre is $9.3 \%$, ash is 0.68 and carbohydrate is $5.15 \%$. Maximum storage life is 7 days under refrigeration temperature without any indication for microbial growth and there was no change in organoleptic quality. It is a microbiologically safe product with 0.15 titratable acidity and 6.66-6.70 $\mathrm{pH}$ range. There was no Coliform growth observed in this selected best sample.
\end{abstract}


The flavor profile modification of selected best formula is recommended further and the study about the natural available stabilizing agent and heat sterilization method should be study further. 